\title{
Spinal T.V.T. Treated with Surgical Excision and Chemotherapy in a Dog
}

\author{
Monica Vicky Bahr Arias, Larissa Garbelini Valentim \& Bianca Ishikawa
}

\begin{abstract}
Background: Canine transmissible venereal tumor (TVT) is a round-cell tumor of dogs, which occurs by cell transplantation. It is usually located on the external genitalia, and is transmitted by coitus. It may occasionally be acquired by sniffing or licking the genitalia of an affected animal. Lesions may be present in the other parts of the body, such as the skin, rectum, and nasal or oral cavities. Metastasis of the TVT is uncommon, mainly occurring in immunocompromised dogs. It may affect organs such as the liver, spleen, kidney, lung, and musculature, and rarely, may be detected in the central nervous system. In this report, we describe the occurrence of a TVT causing spinal cord compression in a dog, and the results of its treatment with hemilaminectomy and chemotherapy.

Case: A six-year-old male Dalmatian dog was referred to a veterinary teaching hospital with nonspecific abdominal pain. Laboratory examination showed no abnormalities; survey radiography revealed a moderate fecal retention. The dog received painkillers and dietary guidelines. However, the patient was brought again to the veterinary teaching hospital nine days later with paraplegia, worse in the left limb than in the right, but with normal nociception. There was a cutaneous trunci reflex cut-off at the T10 vertebra, also worse on left side than on right, along with spinal thoracolumbar hyperesthesia. During endotracheal intubation for general anesthesia for performing a cerebrospinal fluid tap and myelography, a small mass was observed in the palatine tonsil, a sample of which was collected for cytological analysis. The cerebrospinal fluid examination showed albuminocytologic dissociation, and myelography revealed an asymmetrical epidural compression over the T8 vertebra. Surgery was performed with a lateral approach to the T8 vertebra, and a 3 -cm epidural brown mass was found, which was completely excised and subjected to histopathological examination. The histopathological findings of the mass excised from the spine revealed neoplastic proliferation of poorly differentiated, round tumor cells with large, round, central or peripheral nuclei, and slightly eosinophilic, occasionally vacuolar cytoplasm. The propagating cells formed groups separated by a delicate fibrovascular stroma, consistent with the histopathology of TVT. Upon immunohistochemical staining, the neoplastic cells were found to be positive for MHC II, CD45RA, and lysozyme, but negative for cytokeratin, CD3, CD20, and CD117. The cytological examination of the tonsillar mass confirmed TVT. The dog was treated with vincristine, but after the third cycle the treatment was discontinued due to the choice of the owner. A year after the treatment, the dog presents only a mild spinal ataxia.

Discussion: Tumor cells can be transmitted through genital mucous membrane-contact at coitus. Hence, the TVT lesions are often located on the external genitalia, but this was not observed in this case. Non-cutaneous metastases, which have an incidence of about $1 \%$, can occur on the lips and tonsils, as was observed in the present case, or in the inguinal lymph nodes, liver, kidneys, mesentery, bones, eye, brain, and abdominal cavity. The pathological characteristics of TVT is quite variable and depends on the host immune response; however, there was no evidence of immunosuppression or malnutrition in the present case. The patient might have acquired the neoplasia in the oral cavity probably from licking or sniffing the preputial or vaginal discharges of an infected dog, and therefore, the primary tumor was probably the one in the tonsil, which later metastasized to the spine. This case presents an atypically located TVT, without genital occurrence, that was successfully treated by surgery and chemotherapy. This report also indicates that TVT is also an important differential diagnosis of spinal neoplasia.
\end{abstract}

Keywords: spinal neoplasms, canine transmissible venereal tumor, treatment. 


\section{INTRODUCTION}

Canine transmissible venereal tumor (TVT) is a well-characterized, round-cell tumor, which occurs by cell transplantation, that is usually located on the external genitalia of dogs $[13,14]$. The metastasis of TVT is uncommon, mainly occurring in immunocompromised dogs $[6,11,13]$. Most of the reported cases of metastasis are actually mechanical extensions of growth or transplantations to the skin, cervix, uterus, or fallopian tubes from the primary tumor at the external genitalia $[4,11]$. However, distant metastasis to the inguinal lymph nodes, brain, eye, vertebral column, adenohypophysis, and liver have been reported $[2,4-$ $6,13,19,21]$.

This report describes a case of a TVT localized in the epidural region of T8 and T9 vertebrae, causing spinal cord compression in a dog, and its successful treatment by hemilaminectomy and chemotherapy.

\section{CASE}

A six-year-old male Dalmatian dog was presented to a Veterinary Teaching hospital for the evaluation of a nonspecific abdominal pain. Laboratory examination showed no abnormalities, and survey radiography revealed a moderate fecal retention. The dog received painkillers and dietary guidelines. However, the patient was brought in again, nine days later, with paraplegia (Figure 1), worse in the left limb than in the right; nociception was, however, preserved. There was a cutaneous trunci reflex cut-off at the T10 vertebra, worse on the left side than on the right, and upon epaxial palpation, spinal thoracolumbar hyperesthesia was observed. A complete blood count (CBC) revealed neutrophilia $\left(13,916 \mathrm{~mm}^{3}\right)$ and lymphopenia (280 $\mathrm{mm}^{3}$ ), while serum biochemistry revealed increased total serum protein $(8.27 \mathrm{~g} / \mathrm{dL})$ and glucose levels (118 $\mathrm{mg} / \mathrm{dL}$ ). On the basis of these findings, the lesion could be localized neuroanatomically between the T3 and L3 vertebrae, and the main differential diagnosis were inflammatory, infectious, neoplastic, and/or degenerative diseases. Therefore, cerebrospinal fluid (CSF) analysis and imaging studies were proposed in order to arrive at a definitive diagnosis.

For performing the CSF tap and myelography, anesthesia was induced with propofol (Propovan $\left.{ }^{\circledR}\right)^{1}$ and diazepam ${ }^{2}$. During endotracheal intubation, a mass in the palatine tonsil was noticed, and a sample of which was collected for cytological analysis. The CSF examination revealed albuminocytologic dissociation (protein $=88.9 \mathrm{mg} / \mathrm{dL}$ ), while myelography revealed an asymmetrical epidural compression on the left side of the T8 vertebra (Figure 2). An exploratory surgery was proposed, and while awaiting the decision of the owner, the patient was treated with tramadol chlorhydrate ${ }^{3}$ (3 $\mathrm{mg} / \mathrm{kg}$, IV, TID), prednisolone $(0.5 \mathrm{mg} / \mathrm{kg}, \mathrm{VO}, \mathrm{BID}$, for five days), and diazepam ${ }^{2}(0.5 \mathrm{mg} / \mathrm{kg}, \mathrm{IV}, \mathrm{TID})$, following which, normal defecation resumed.

The dog underwent an exploratory surgery six days later. Sedation was performed with acepromazine (Acepran $\left.{ }^{\circledR}\right)^{4}[0.03 \mathrm{mg} / \mathrm{kg}, \mathrm{IM}]$ and meperidine ${ }^{5}(3 \mathrm{mg} /$ $\mathrm{kg}$, IM). Cephazolin ${ }^{6}(30 \mathrm{mg} / \mathrm{kg}$, IV) was administered prophylactically before and at the end of the surgery. Anesthesia was induced with propofol (Propovan $\left.{ }^{\circledR}\right)^{1}$ and diazepam ${ }^{2}$, and maintained with isoflurane (Isoforine ()$^{1}$ in oxygen. The thoracolumbar spine was approached dorsolaterally, and a left side-hemilaminectomy was performed on the $\mathrm{T} 7$ and $\mathrm{T} 8$ vertebrae. A brown epidural mass, $3 \mathrm{~cm}$ in length, was found upon exposing the vertebral canal (Figure 3 ). This mass was carefully excised and subjected to histopathological examination. After surgery, the signs of pain were assessed by physical examination, and postoperative analgesia was ensured with the continuous infusion of MLK [morphine (Dimorf®) ${ }^{1}$, lidocaine (Xyleste$\sin ()^{1}$, and ketamine $\left.\left(\text { Ketamin }{ }^{\circledR}\right)^{1}\right]$ and ketoprofen ${ }^{1}$ $(1 \mathrm{mg} / \mathrm{kg}, \mathrm{SC}, \mathrm{SID})$ for two days. The administration of prednisolone was discontinued before the surgery, and ketoprofen, introduced after the surgery.

The cytological findings of the tonsillar mass revealed a neoplastic round-cell population with features of malignancy including mild to moderate anisocytosis, anisokaryosis, and numerous mitotic figures, characteristic of TVT. Histopathological findings of the mass excised from the medullar canal revealed a neoplastic proliferation of poorly differentiated, round tumor cells with large, round, central or peripheral nuclei, and little abundant, slightly eosinophilic, occasionally vacuolar cytoplasm. The propagating cells formed groups separated by a delicate fibrovascular stroma. The mitotic index was three mitosis per 40 high power fields (HPF), and the infiltration of lymphocytes and plasmocytes was observed, consistent with the histopathology of TVT. The findings of immunohistochemical staining (IHC) revealed that the neoplastic cells were positive for MHC II, CD45RA, 
and lysozyme, but negative for cytokeratin, CD3, CD20, and CD117 antibodies (Figure 4).

Eight days post-surgery, the patient presented appreciable neurological improvement, albeit showing ataxia (Figure 5A). Regarding to this, diagnostic findings were consistent with TVT, and a genital examination was performed, but no preputial or penile mass was present or palpated. However, when the stitches were removed, the presence of a left labial mass, an increase in the size of the left submandibular lymph node, and another mass next to the second right mamma were observed. A cytological examination of the aspirate from the mammary nodule revealed the same features as the tonsillar and spinal masses, thus confirming metastasis to the mammary region; the aspirate from the labial mass was inconclusive, and the submandibular lymph node was actually found to be an enlarged salivary gland.

Treatment with vincristine sulfate $(0.75 \mathrm{mg} /$ $\mathrm{m}^{2}$, IV, q 7 days) was then initiated. A CBC profile was performed every week. After three applications of

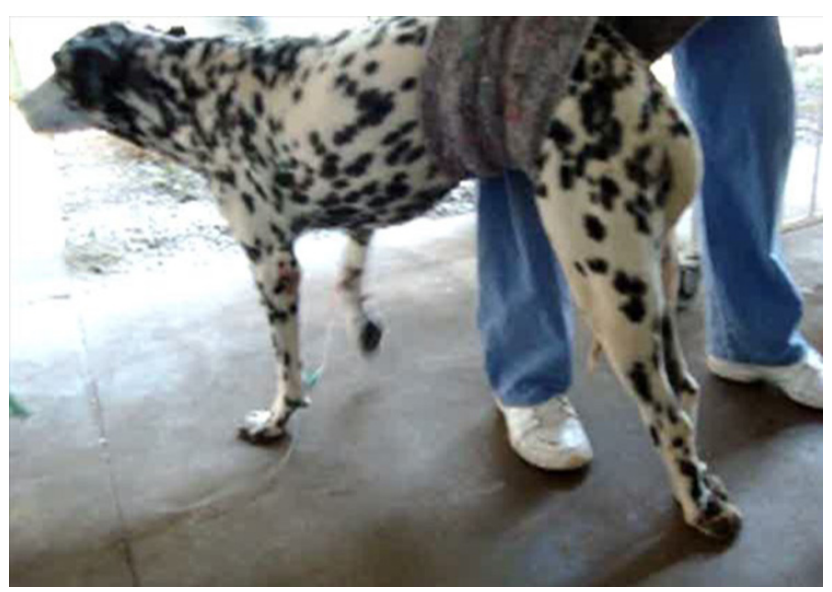

Figure 1. The pacient with paraplegia.

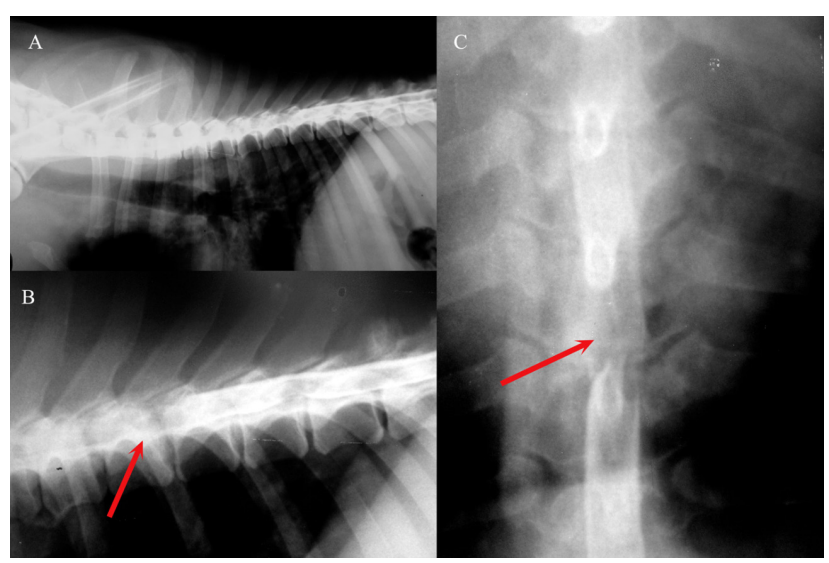

Figure 2. A \& B- lateral myelography. An irregular contrast column can be seen (red arrow). C- ventrodorsal myelography. A lateralized compression over the left side of T8 can be seen (red arrow). vincristine, leukopenia was noticed $\left(4,100 \mathrm{~mm}^{3}\right)$, which was attributed to the bone marrow suppression due to the vincristine treatment. The owner, therefore, chose to stop the treatment. However, the dog continued to improve (Figure 5B), and remained well even one year post-surgery, showing only mild proprioceptive ataxia.

\section{DISCUSSION}

Transmissible venereal tumor (TVT) primarily affects the genitalia of sexually mature dogs $[11,13]$. Since it is transmitted by the contact of genital mucous membranes at coitus $[6,9,13,14]$, the lesions are often located on the external genitalia $[13,14]$. In this case, the tonsillar TVT tumor was suspected to be the primary tumor, since no external lesions were visible upon genital examination and the skin lesions only appeared after surgery. The patient might have acquired the neoplasia in the oral cavity probably from licking or sniffing the preputial or vaginal discharges of an infected dog $[4-6,8,10,13]$. Non-cutaneous metastasis occur in about $1 \%$ of the cases, and can occur on the lips, tonsils, and skin [2,6,13], as was observed in this case. Other locations are the inguinal lymph nodes, liver, kidneys, mesentery, bones, eye, brain, and abdominal cavity $[2,6,13]$. The pathological characteristics of TVT is quite variable and depends on the host immune response $[6,11,13]$. However, there was no evidence of immunosuppression or malnutrition in the case reported here. It can't be affirmed that the patient has no presented a genital mass before the neurologic involvement, but according to Ganguly et al.[6], the TVT after a logarithmic growth regresses spontaneously in most healthy adult dogs, and after a complete regression, the development of tumor immunity prevents successive occurrences, so if the patient once had a genitalia mass and it had spontaneous cure, this animal should have tumor immunity which wouldn't allow the progression of the spinal tumour.

The cytological examination of the tonsillar tumor, histological examination of the spinal mass, and IHC staining aided in the differentiation of the TVT from other round cell tumors [8]. Cytological examination provides better evidence of TVT than does histological examination [5,6,20], as was evident from the cytological findings of the tonsillar and lip tumors in this case. The histological appearance of TVTs might be difficult to distinguish from other round cell tumors, such as histiocytomas, lymphosar- 


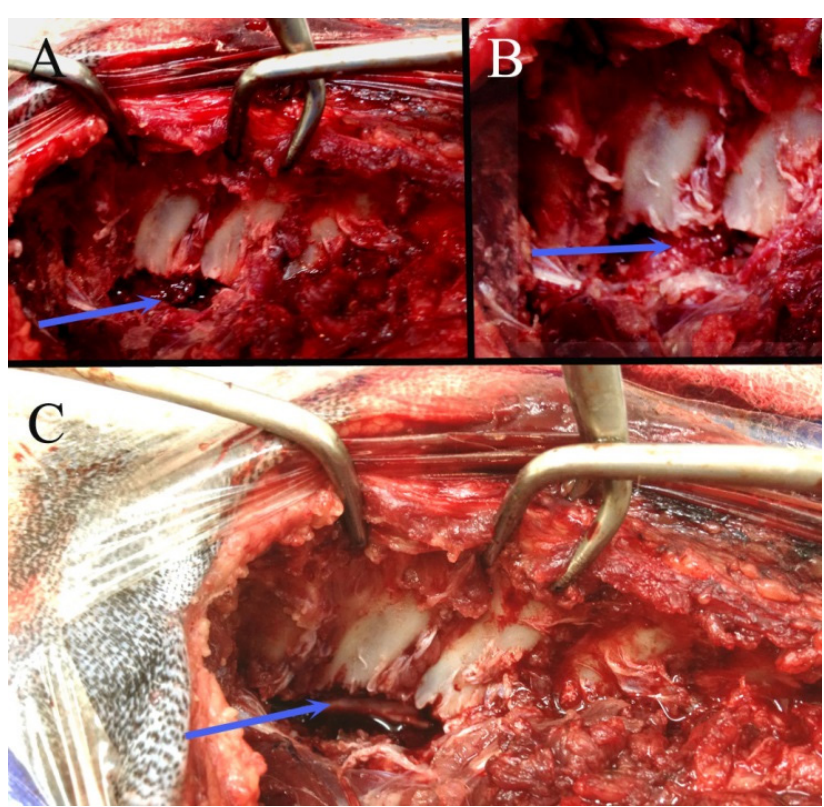

Figure 3. Intraoperative images during the excision of the TVT. A left side hemilaminectomy was performed on the T8 and T9 vertebrae. A \& B- a brown mass can be seen (blue arrow). C- the spinal cord can be seen after the complete excision of the TVT (blue arrow).

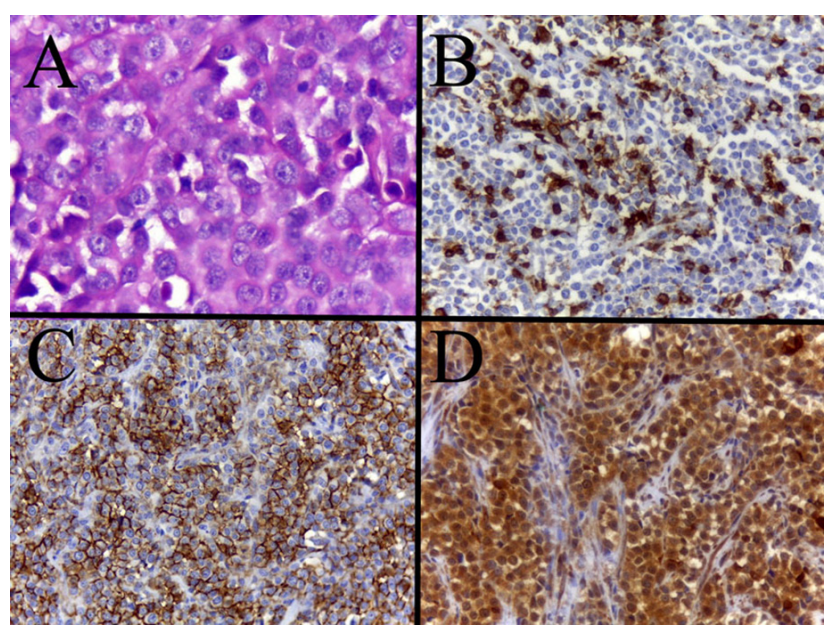

Figure 4. A- histological findings. Hematoxylin and eosin (HE) staining: Numerous round-to oval-shaped cells with multivacuolated cytoplasm are seen; the cells are poorly differentiated and exhibit a large, round nucleus at the center or shifted to the periphery. By immunohistochemical staining, the neoplastic cells were found to be positive for MHC II (B), CD45RA (C), and lysozyme (D), but negative for cytokeratin, CD3, CD20, and CD117.

comas, or mast cell tumors, especially when the tumor is located on the extra-genital areas [11]. Therefore, the diagnosis of TVT should be further supported by IHC staining $[4,7,8,18]$. In our case, the results of the IHC staining allowed the exclusion of lymphoma and indicated the expression of lysozyme, which was consistent with the findings of other reports of TVT [11]. The CSF examination revealed albuminocy- tologic dissociation, i.e., an increase in the amount of proteins without a corresponding increase in the number of cells, which is seen in cases of nervous system neoplasia [17]. The asymmetrical, high thoracolumbar localization of the tumor increased the suspicion of neoplasia in our case, because this region is predisposed to the occurrence of neoplasias [1], and in addition, the neoplasias located on the spinal cord tend to show asymmetrical occurrence [19].

Several treatments including surgery, radiotherapy, immunotherapy, biotherapy, and chemotherapy have been applied for TVT [4,7,16,21]. Currently, the intravenous administration of vincristine at a dosage of $0.5 \mathrm{mg} / \mathrm{m}^{2}$ of body surface, once a week, for 2-6 weeks, is the treatment of choice, independent of the size of the neoplasm and the presence or absence of metastases [6,21], but since the vincristine has negligible penetration of the brain barrier [12], it was used in a higher dose. In this case, the application of vincristine for three weeks was sufficient to eliminate the tonsillar and lip tumors, thus preventing the recurrence of the spinal tumor. Chemotherapy may cause transient leukopenia that can force the discontinuation of one or more chemotherapy administrations. However, this has been reported to occur in less than $2 \%$ of the subjects under chemotherapy treatment [7].

Surgery was effective in this case for the diagnosis, spinal cord decompression, collection of the biopsy material, and treatment. Surgical excision should be performed on those dogs that present small, easily accessible, non-invasive tumor nodules [7] since it is possible to remove the entire mass with good surgical margins, as was the case in the present report.

There are few reports of the metastasis of TVTs to nervous system $[3,4,15,16]$. In one of the reports, a dog presented with an ocular TVT; despite an initial improvement with chemotherapy, the patient later presented with seizures. A brain metastasis was then diagnosed, and the owner chose to euthanize the dog [4]. In another report, a female dog presented with nodules in the vagina, skin, and eye, and upon a slight improvement with vincristine, was treated with doxorubicin, which also brought about some improvement. However, the dog later presented cerebral signs and died; a thalamic mass was found upon necropsy [3]. In yet another case, a dog that presented with TVT in the penis and tetraparesis with cervical pain was 


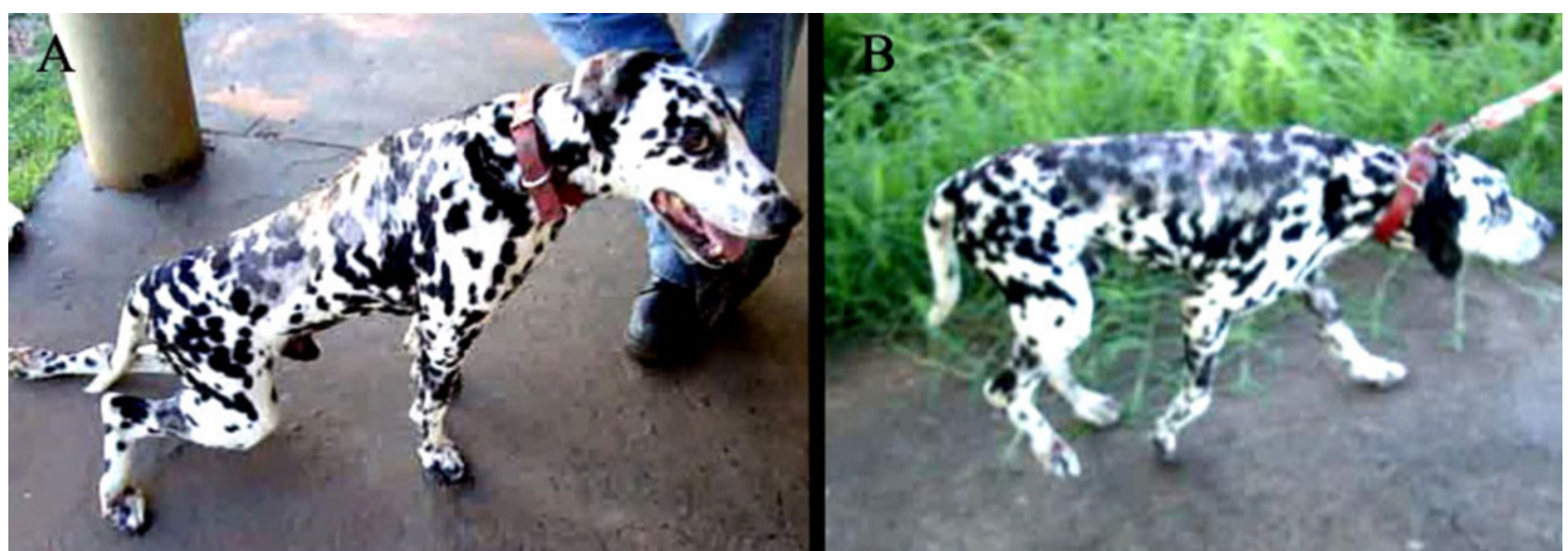

Figure 5. A- the pacient showing paraparesis eight days post-surgery. B- the same dog walking despite a mild spinal ataxia 30 days post-surgery.

euthanized, and during necropsy, metastasis in the liver and vertebral plexuses of the $\mathrm{C} 3$ and $\mathrm{C} 4$ vertebrae were found [19]. Thus, it can be seen that there were no reports of dogs with spinal TVT that showed improvement after medical and/or surgical treatment.

This report provides evidence supporting the importance of considering TVT as a differential diagnosis in cases of spinal neoplasia in dogs.

\section{MANUFACTURERS}

${ }^{1}$ Cristália Produtos Químicos Farmacêuticos. Itapira, SP, Brazil. ${ }^{2}$ Laboratório Teuto Brasileiro S/A. Anápolis, GO, Brazil.

${ }^{3}$ Fresenius - Kabi. Aquiraz, CE, Brazil.

${ }^{4}$ Vetnil Produtos Veterinários. Louveira, SP, Brazil.

${ }^{5}$ União Química. São Paulo, SP, Brazil.

${ }^{6}$ ABL. Antibióticos do Brasil. São Paulo, SP, Brazil.

Declaration of interest. The authors report no conflicts of interest. The authors alone are responsible for the content and writing of the paper.

\section{REFERENCES}

1 Costa R.C. 2008. Neoplasias do Sistema nervosa. In: Oncologia em cães e gatos. São Paulo: Roca, pp.411-436.

2 Cruz G.D., Santos C.F., Santos C.R., Ruschi C.S., Elias T., Xavier J.G. \& Bonamin L.V. 2009. Metástase visceral de tumor venéreo transmissível em cão. Veterinária e Zootecnia. 16: 465-470.

3 Fernandes C.P.M, Gaspar L.F.J, Meinerz A.R.M., Grecco F.B., Nobre M.O. \& Cleff M.B. 2013. Tumor Venéreo transmissível canino com metástase encefálica. Semina: Ciências Agrárias. 34(6): 3929-3933.

4 Ferreira A.J., Jaggy A., Varejão A.P., Ferreira M.L., Correia J.M., Mulas J.M., Almeida O., Oliveira P. \& Prada J. 2000. Brain and ocular metastases from a transmissible venereal tumour in a dog. Journal of Small Animal Practice. 41(4):165-168.

5 Filgueira K.D. 2010. Tumor venéreo transmissível canino com localização primária e única em cavidade oral. Acta Scientiae Veterinarie. 38(1): 91-94.

6 Ganguly B., Das U. \& Das A.K. 2016. Canine transmissible venereal tumour: a review. Veterinary and Comparative Oncology. 14: 1-12.

7 Gonzalez C.M., Griffey S.M., Naydan D.K., Flores E.R., Cepeda R., Cattaneo G. \& Madewell B.R. 2000. Canine Transmissible Venereal Tumour: a Morphological and Immunohistochemical Study of 11 Tumours in Growth Phase and during Regression after Chemotherapy. Journal of Comparative Pathology. 122: 241-248

8 Mazos E., Méndez A., Gómez-Villamandos J.C., Martín de las Mulas J. \& Pérez J. 1996. Immunohistochemical Characterization of Canine Transmissible Venereal Tumor. Veterinary Pathology. 33: 257-263.

9 Mello Martins M.I., Ferreira de Souza F. \& Gobello C. 2005. The Canine Transmissible Venereal Tumor: Etiology, Pathology, Diagnosis and Treatment. In: Recent Advances in Small Animal Reproduction, Concannon P.W., England G., Verstegen III J. and Linde-Forsberg C. (Eds.). International Veterinary Information Service, Ithaca NY: A1233.0405 [Source: <http:// http://www.ivis.org/advances/Concannon/gobello2/chapter.asp?LA=1>]. [Accessed August 2015].

10 Papazoglou L.G., Koutinas A.F., Plevraki A.G. \& Tontis D. 2001. Primary Intranasal Transmissible Venereal Tumour in the Dog: A Retrospective Study of Six Spontaneous Cases. Journal of Veterinary Medicine. 48(7): 391-400

11 Park M., Kim Y., Kang M.S., Oh S.Y., Cho D.Y., Shin N.S. \& Kim D.Y. 2006. Disseminated transmissible venereal tumor in a dog. Journal of Veterinary Diagnostic Investigation. 18: 130-133. 
12 Rodaski S. \& De Nardi A.B. 2008. Fármacos Naturais. In: Quimioterapia antineoplásica em Cães e Gatos. São Paulo: Medvet, pp.92-112.

13 Rogers K.S. 1997. Transmissible venereal tumor. Compendium of Continuing Education Practice Veterinary. 19: 1036-1042.

14 Rogers K.S., Walker M.A. \& Dillon H.B. 1998. Transmissible Venereal Tumor: A retrospective study of 29 cases. Journal of the American Animal Hospital Association. 34: 463-470.

15 Santos F.G.A, Vasconcelos A.C., Nunes J.E.S., Cassali G.D., Paixão T.A. \& Moro L. 2005. O tumor venéreo transmissível canino - aspectos gerais e abordagens moleculares (Revisão de literatura). Bioscience Journal. 21(3): 41-53.

16 Santos J.P., Barbosa M.A.G., Tenório A.P.M., Coelho M.C.O.C., Rolim M.B.Q \& Tudury E.A. 2008. Tumor venéreo transmissível em um canino com acometimento de pele. Medicina Veterinária. 2(2): 39-43.

17 Seguin B., Bagley R.S., Silver G.M. 2000. Diagnosis and treatment of spinal neoplasia in dogs and cats. WALTHAM Focus. 10: 4-9.

18 Stockmann D., Ferrari H.F., Andrade A.L., Lopes R.A., Cardoso T.C \& Luvizotto M.C.R. 2011. Canine Transmissible Venereal Tumors: Aspects Related to Programmed Cell Death. Brazilian Journal of Veterinary Pathology. 4(1): 67-75.

19 Tudury E.A., Loureiro Bracarense A.P.F.R., Giraldi J.H. \& Bahr Arias M.V. 1992. Metástase vertebral de tumor venéreo transmissível em cão. Revista Cães \& Gatos. 7: 27-28.

20 Ulčar I., Celeska I., Ilievska K., Atanaskova E., Nikolovski G. \& Trojačanec P. 2013. Cytological diagnostic of canine transmissible venereal tumor - Case report. Macedonian Veterinary Review. 35(2): 91-96.

21 Varughese E.E., Singla V.K., Ratnakaran U. \& Gandotra V.K. 2012. Successful management of Metastatic Transmissible Venereal Tumor to Skin of Mammary Region. Reproduction in Domestic Animals. 47(6): 366-369. 